\title{
A Field Experiment to Test the Labor Market Value of a Credential from a For-Profit Postsecondary School
}

\author{
Carolyn Arcand \\ University of New Hampshire
}

\begin{abstract}
The attainment of postsecondary credentials holds particular promise in improving economic security for low-income single mothers. However, the type of school attended may matter when determining whether postsecondary credentials will foster positive labor market outcomes and financial stability for former students. This paper describes the pretest of a field experiment to examine whether the school type listed on a job applicant's resume has an impact on receiving a call for a job interview, in fields commonly pursued by low-income women. School types tested were for-profit schools and community colleges. Results revealed little difference in outcomes for job seekers with credentials from each school type. However, more reliable results could be obtained by repeating this study in a stronger economy, using job candidates with minimal applicable experience, applying to a greater number of positions, and selecting occupations for which an academic credential is widely seen as a prerequisite for entry.
\end{abstract}

Keywords: labor market outcomes, community college, for-profit school, low-income women

Postsecondary education has traditionally been viewed as a pathway out of poverty, through its emphasis on the development of skills that are valued and highly compensated in the labor market. The attainment of postsecondary credentials may be particularly beneficial for low-income single mothers, a group that has historically faced numerous challenges in the labor market. These challenges include wage gaps associated with gender and motherhood status, occupational segregation into lower-paying, traditionally female-dominated fields, and working in jobs with little flexibility to juggle personal obligations (Anderson, Binder, \& Krause, 2003; Blau, Ferber, \& Winkler, 2006; Figart, Mutari, \& Power, 2002; Institute for Women's Policy Research, 2011). For this group, postsecondary education can help to overcome (or at least minimize) these challenges and should translate into the attainment of a "good" job - one that is stable, with a higher salary and fringe benefits.

The type of school attended may matter when determining whether the attainment of a credential will lead to financial stability. Students attending for-profit postsecondary schools are defaulting on student loans at more than double the default rate for borrowers at other types of schools. Almost 23 percent of federal student loan borrowers who attended for-profit institutions and who entered repayment in 2009 had defaulted on their 
loans by 2012 (U.S. Department of Education, 2012). In contrast, just 11 percent of public school students in the same cohort defaulted on student loans within three years of entering repayment (U.S. Department of Education, 2012). These default rates suggest that for-profit students are not achieving the financial stability ostensibly fostered by postsecondary education to the same degree as their peers attending public schools.

While community colleges have traditionally acted as the primary provider of postsecondary education for low-income students (Levine \& Nidiffer, 2006), for-profit schools have emerged as an increasingly popular option in recent years (Lynch, Engle, \& Cruz, 2010). For-profit schools (also known as proprietary schools) are owned by private corporations or held by publicly traded companies, and they typically offer practical, career-based education (Kutz, 2010; Yeoman, 2011). Most operate through online coursework and concentrate on the development of specific job skills (Harkin, 2011; Cohen \& Kisker, 2009). Many hold classes continuously, year-round (Kutz, 2010). These schools have been lauded for their accessibility, flexibility, and ability to cater to the needs of nontraditional students (those that are older, financially independent, and more likely to have family responsibilities and full-time jobs while attending school). However, they are becoming known for their students' high rates of loan default as well.

One reason for greater default rates is likely the higher cost of education at for-profit schools relative to public colleges. However, it might also be the case that school type affects former students' labor market experiences, thus impacting financial stability. Unemployment and low income levels are overlapping factors that are associated with loan default (Gross, Cekic, Hossler, \& Hillman, 2009; Loonin, 2012). Could school type potentially impact former students' labor market experience when searching for jobs, thus affecting employment status and income level? More broadly, does school type matter to employers screening job candidates for open positions? If students attending for-profit schools are less likely to be hired by employers, this disadvantage could lead to unemployment and eventual student loan default. The consequences of this type of a disadvantage could be particularly dire for low-income single mother students, who take out larger loans than their married parent and non-parent peers (Miller, 2012) and may therefore face larger loan payments and feel more intense pressure to find a good job quickly after leaving school.

This study involved the use of a field experiment pre-test to determine whether school type has an impact on labor market experience, in two fields commonly pursued by low-income women with associate's degrees or subbaccalaureate certificates. While prior research has looked into causes of loan default, few studies have considered differences in the ability of students with similar educational credentials from different types of schools to get a job. 


\section{Statistical Discrimination and Employer Perceptions of Educational Credentials}

Phelps (1972) introduced the theory of statistical discrimination related to employer hiring decisions. This theory posits that employers making hiring decisions often make generalizations related to potential productivity based on a job applicant's visible characteristics (e.g. gender or skin color). In instances where tracking down information about productive capacity for each of a large number of candidates would be costly, utilizing generalizations constitutes a valuable shortcut. For example, in assessing two candidates in their mid-twenties, an employer making a hiring decision may choose a male candidate over a female candidate based on a preconception that the female candidate would be more likely to take time away from the labor market to raise children or tend to family needs, and thus would ultimately prove less productive than the male candidate. Prior studies have validated the use of statistical discrimination based on race (Pager, Bonikowski, \& Western, 2009) and gender (Bielby \& Baron, 1986) in hiring.

Statistical discrimination may ostensibly occur based on preconceived notions of the productive capacity of job seekers who attended different types of postsecondary schools. This could happen if one school type is perceived as being of a lesser quality and conveying substandard training to its students. Job seekers who attended the "substandard" school may then be viewed as having fewer productive capabilities than students who completed similar programs at higher-quality schools.

Comparing the perceived quality of different types of schools in the labor market presents a challenge, as educational quality is a somewhat subjective concept that is difficult to measure. Cohen and Kisker's (2009) theory of academic currency helps to explain why employers may perceive postsecondary credentials from different institutions as having varied impact on student productivity. In developing the notion of academic currency, Cohen and Kisker (2009) conceive of the system of higher education as essentially comprised of a set of concentric circles, "with the liberal arts colleges and research universities at the core. Further out are the comprehensive institutions [like state colleges], then community colleges, and at the exterior, the proprietary [for-profit] schools. Each sector is perceived by its staff, alumni, supporters, funding agents - the public at large - as having a certain worth" (p. 462).

The institutions comprising the innermost circle (liberal arts colleges and research universities) are the most selective with students and faculty, as well as the most well-endowed financially. Moving out through the circles, schools become less selective (with both admissions policies and 
faculty achievement criteria), may have lower costs or revenues, and focus increasingly on immediate career preparation with fewer years of study. Students will have an easy time moving from the center of the circles to the outer realm, as credits from core institutions are highly transferable to other types of schools. On the other hand, credits from outer institutions tend to be less transferable for students seeking to move inward towards the core. Cohen and Kisker note that "Practically no credits earned at proprietary schools can be used towards degrees at liberal arts colleges, whereas credits from one of the core institutions are accepted at almost all the others" (p. 462-463). Based on this notion of transferability within institutions, different types of schools appear to hold varying levels of academic currency, defined by Cohen and Kisker as the relative value of credentials (in this case, credits) from a particular type of school as seen by other types of educational institutions. The notion of academic currency is illustrated in Figure 1.

Figure 1: The Higher Education System and the Hierarchy of Academic Currency

Adapted from Cohen and Kisker, 2009

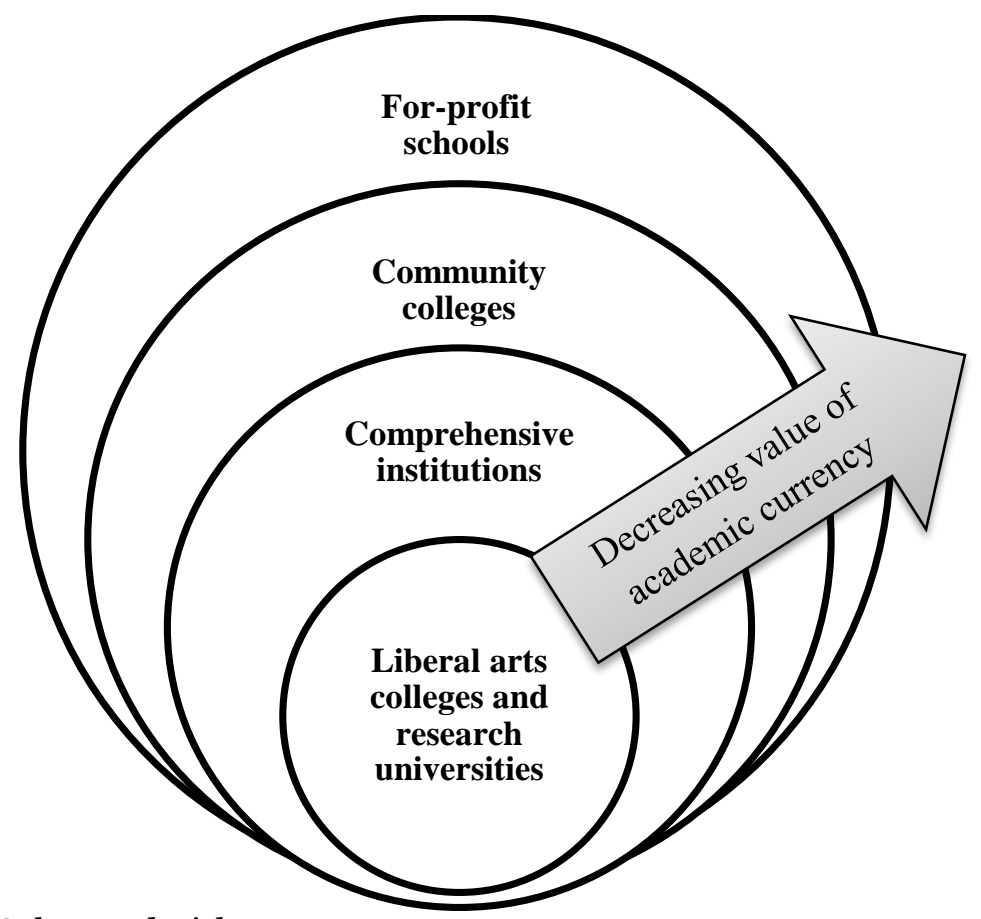

The idea of academic currency may be extended to the labor market. Holding all else equal, an employer may assume that a job candidate with a degree from a prestigious liberal arts college or known research university will be more productive than a candidate with the same degree from a state, community, or for-profit college. This may be due to common knowledge 
regarding core institutions' admission standards or the deduction that prestigious faculty may better prepare students for their chosen fields than those at, for example, for-profit schools. Better-prepared students will presumably be more productive than students with less exhaustive or lowerquality preparation. This theory supports the idea that credentials from forprofit institutions may carry substandard value in the labor market, which could hinder graduates as they compete for employment alongside graduates from other, more highly ranked, institutions.

If for-profit credentials are viewed as being of substandard quality, then students exiting these schools will undoubtedly have trouble exercising their capabilities in the labor market on a level playing field with graduates from other types of schools. Low-income single mother students, who are already subject to labor market challenges, may be particularly disadvantaged by a for-profit credential and thus less likely to obtain gainful employment and more likely to ultimately default on student loans.

\section{Methods}

The field experiment pre-test to explore the labor market value of a credential from a for-profit school was conducted over a six month period in fall 2012 and spring 2013. Field experiments have proven to be a useful way of measuring statistical discrimination based on employer perceptions of job candidate attributes (see for example Bertrand \& Mullainathan, 2004; Widner \& Chicoine, 2011). While high student loan default rates associated with students leaving for-profit schools suggest that this type of an education may not pay off in the labor market to a similar extent as an education from other types of schools, a field experiment can more directly test how employers view for-profit credentials when screening job applicant resumes and whether statistical discrimination may be a factor.

In this experiment, the perception of the value of credentials from forprofit schools was tested against the perception of the value of credentials from community colleges (an institution that is one level above for-profit schools in the hierarchy of academic currency). The experiment involved applying to job openings in two fields commonly pursued by low-income women who have fully or partially completed sub-baccalaureate certificates or associate's degrees. These credential levels were chosen since the majority of low-income female students (55.7\%) attend a two-year (or less) postsecondary institution (Center for Women Policy Studies, 2004). Lowincome single mother students are significantly more likely than other students to cite the pursuit of a certificate or associate's degree as their initial goal upon entering school, and are also more likely to attend forprofit schools (Arcand, 2013). As highly nontraditional students, lowincome single mothers are particularly at risk for dropping out of school (Swail, 2009); thus some job applications listed the completion of a 
credential under educational attainment, while others listed partial completion of a program.

Over the six month pre-test period, two resumes were sent to each job posting appearing on two popular job search web sites, for positions in the Boston area in the two chosen fields. The websites used were indeed.com and boston.craigslist.org. Indeed.com is an international search engine that scans employment listings from a large variety of sources for job-seekers, presenting links to listings from many different sources (newspapers, company web sites, etc.) in one place. The U.S. site receives 17 million unique visitors each month (Shontell, 2012). Boston.craigslist.org is the Boston area page of the larger community-moderated site craigslist.org, which hosts community forums and classified ads by geographical area (Craigslist.org, 2012). Searches on both sites were restricted to open positions posted in cities and towns within a ten mile radius of Boston.

For each position advertised, two substantively identical resumes (in terms of work experience, skill sets, etc.) were submitted for consideration. One resume listed the candidate's postsecondary education as being from a for-profit school; the other listed a Massachusetts community college. Both resumes reflected candidates with similarly racial-sounding names (randomly alternating "African-American" and "white" sounding names for each position). Prior field experimentation using this method has found that employers respond differently to candidates based on perceived race, and candidates with non-white sounding names receive fewer job callbacks than candidates with white sounding names (Bertrand \& Mullainathan, 2004; Widner \& Chicoine, 2011). This treatment controlled for race and allowed for the analysis of outcomes by school type along with racial comparisons.

During the course of the experiment, all open job positions posted in each field were randomly assigned to one of four groups. Each job posting was sent two applications from its assigned group, as follows:

Group 1. One resume listed a fully completed Associate's degree or certificate from one of two community colleges, and one resume listed a fully completed Associate's degree or certificate from one of two forprofit schools. Both resumes listed African-American sounding candidate names.

Group 2. One resume listed a fully completed Associate's degree or certificate from one of two community colleges, and one resume listed a fully completed Associate's degree or certificate from one of two forprofit schools. Both resumes listed white sounding candidate names.

Group 3. One resume listed a partially completed Associate's degree or certificate from one of two community colleges, and one resume listed a partially completed Associate's degree or certificate from one of two forprofit schools. Both resumes listed African-American sounding candidate names. 
Group 4. One resume listed a partially completed Associate's degree or certificate from one of two community colleges, and one resume listed a partially completed Associate's degree or certificate from one of two forprofit schools. Both resumes listed white sounding candidate names.

A voice mailbox and email address were set up and associated with each treatment (candidate name/school type combination), and the number of calls for interviews received by each candidate name/school type combination were recorded.

\section{Determining Occupational Fields}

To determine which occupational fields to use in the experiment, information on occupations primarily held by women was obtained from the Bureau of Labor Statistics (BLS). The BLS administers the Current Population Survey, a monthly survey of 60,000 American households which collects detailed employment data. From this survey, the BLS released a list of total employed individuals in various occupations within the American labor market, as well as total women in each field, for 2011 (Bureau of Labor Statistics, 2012a). This information was reviewed and all occupations where women comprise at least $85 \%$ of employees were listed.

Next, BLS data on educational attainment by workers in the selected occupational fields was obtained for the most recent year available, 2009. The BLS records the percentage of total employees in each occupation by education level, with levels ranging from less than a high school diploma to a doctoral or professional degree (Bureau of Labor Statistics, 2012b). Occupations in which a greater percentage of workers held either some college/no degree (implying that they may have a certificate or partially completed degree) or an associate's degree, than any other category of educational background, were retained.

As this experiment involved applying for open positions in the Boston area, the next step in selecting two occupations entailed finding those for which individuals in Massachusetts could access training at both community colleges and for-profit schools. A list of the for-profit institutions and Massachusetts community colleges awarding the largest number of associate's degrees and sub-baccalaureate certificates (a combined figure) in 2009-2010 was obtained from the National Center for Education Statistics. For-profit schools that did not have a physical location in Massachusetts or offer degrees online were eliminated based on the rationale that this would make attendance for an individual living in Massachusetts improbable. The top five associate's degree/subbaccalaureate certificate-granting for-profit schools and Massachusetts community colleges were recorded. 
Once the top five for-profit schools and Massachusetts community colleges were determined, the programs offered (associate's degrees and certificates) at each school were examined. Schools offering a degree or certificate advertised as preparing a student for one of the occupations derived from the BLS data were noted. A matrix of all credentials (degrees or certificates) offered by the selected for-profits and community colleges, advertised by the school as preparing students for one of the selected occupations, was compiled. This matrix was assessed to determine occupational fields in which at least two for-profit schools and two community colleges offered similar credentials. (Resumes would utilize the names of two different for-profit schools and two different community colleges for each occupation to reduce the potential for bias associated with employers' possible familiarity with a particular school.) Only two occupational fields met these criteria: (1) bookkeeping, accounting, and auditing clerks, and (2) medical assistants.

The fictitious "job candidates" in this study would live in the Boston area. Since most community college students attend the college nearest to their home (Jepsen \& Montgomery, 2009), it was most realistic to select community colleges located within a reasonable commuting distance from Boston to use as candidates' educational credentials. Three of the preselected community colleges were located within about a half-hour drive from Boston, and were thus chosen for inclusion. Of the pre-selected forprofit schools, those offering complementary educational credentials were also chosen for inclusion in this study based on location: those that were used either had locations within about a half-hour drive from Boston, or offered online credentials. For-profit school credentials were matched with comparable Boston-area community college credentials for similar occupations (for example, resumes would be sent out from candidates that had both received an Associate of Science degree in accounting, either from a for-profit school or a community college). A list of school types, credential names, and locations used for each occupational field are displayed in Table 1.

\section{Creating Resumes}

The creation of substantively similar resumes required assembling a database of candidate names, addresses (email and physical), phone numbers, resume formats, and work experience/skills representative of typical job seekers within each occupation. This information was obtained from several sources.

As part of their field experiment on labor market discrimination, Bertrand and Mullainathan (2004) put together a list of the most common first names given to babies born in Massachusetts between 1974 and 1979, by race, and tested the racial distinctiveness of the top names in a survey in 
ARCAND

Table 1

School Types, Credential Names, and Locations Used for Each Occupational Field

\begin{tabular}{|c|c|c|c|c|}
\hline \multirow[b]{2}{*}{$\begin{array}{l}\text { Occupation } \\
\text { Bookkeeping, } \\
\text { accounting, } \\
\text { and auditing } \\
\text { clerks }\end{array}$} & \multicolumn{2}{|c|}{ For-profit/community college pair 1} & \multicolumn{2}{|c|}{ For-profit/community college pair 2} \\
\hline & $\begin{array}{l}\text { FP, A.S. in } \\
\text { accounting } \\
\text { (online) }\end{array}$ & $\begin{array}{l}\text { CC, A.S. in } \\
\text { accounting } \\
\text { (physical } \\
\text { location in } \\
\text { Boston area) }\end{array}$ & $\begin{array}{l}\text { FP, A.A.S. in } \\
\text { accounting } \\
\text { (online) }\end{array}$ & $\begin{array}{l}\text { CC, A.S. in } \\
\text { accounting } \\
\text { (physical } \\
\text { location in } \\
\text { Boston area) }\end{array}$ \\
\hline $\begin{array}{l}\text { Medical } \\
\text { assistants }\end{array}$ & $\begin{array}{l}\text { FP, A.A.S. in } \\
\text { medical assisting } \\
\text { (physical } \\
\text { location in } \\
\text { Boston area) }\end{array}$ & $\begin{array}{l}\text { CC, A.S. in } \\
\text { medical assisting } \\
\text { (physical } \\
\text { location in } \\
\text { Boston area) }\end{array}$ & $\begin{array}{l}\text { FP, medical } \\
\text { assistant } \\
\text { certificate } \\
\text { (physical } \\
\text { location in } \\
\text { Boston area) }\end{array}$ & $\begin{array}{l}\text { CC, medical } \\
\text { assistant } \\
\text { certificate } \\
\text { (physical } \\
\text { location in } \\
\text { Boston area) }\end{array}$ \\
\hline
\end{tabular}

Note. $\mathrm{FP}=$ for-profit school; $\mathrm{CC}=$ community college; $\mathrm{A} . \mathrm{S}$. = associate in science degree; A.A.S. = associate in applied science degree.

various public areas in Chicago. The names with the highest likelihood of being chosen for white and African-American female babies, which also had high rates of being recognized as connected with racial characteristics, were matched with common white and African-American sounding last names and used in the study. For this research, two African-American and two white-sounding first and last names were randomly selected from Bertrand and Mullainathan's list. For the resumes of "African-American" applicants, the names Keisha Robinson and Kenya Jackson were used, and for the resumes of "white" applicants, the names Anne Ryan and Carrie Baker were used.

Bertrand and Mullainathan's (2004) field experiment on labor market discrimination involved sending out resumes with randomly selected addresses from every zip code in Boston. They found that higher "neighborhood quality" positively impacted the likelihood of callback for an interview. Job applicants living in zip codes determined as being more educated, whiter, or higher-income (based on an analysis of census data) had a higher likelihood of callback for an interview. To control for this, both resumes sent to each open position during this field experiment pre-test displayed addresses from the same zip code.

Four zip codes were randomly selected from a list of all zip codes in the Boston area. A list of all street names in each selected zip code was then obtained, and two street names were randomly selected from each list. A random address number (checked to ensure that it was not associated with an actual residential address) on each street that resulted from the search was selected. These addresses were randomly assigned to job applicants applying to each open position.

In spring 2012, all resumes posted on indeed.com listing accounting, auditing, or bookkeeping within the body of the resume were examined. Those that (a) listed an associate's degree as the top level of education; and 
(b) clearly appeared to be associated with candidates seeking accounting support positions (either through a goal/objective listed on the resume, or through an examination of past experience/education) were downloaded for examination. To avoid too close of a match with current job seekers, resumes were sorted by most recent date updated, and only those updated through the end of calendar year 2011 were considered. Information was compiled from all resumes on skills, years of experience, job titles, past employers, and years at each job. This information was used to create two substantively similar resume work histories and skill sets using average characteristics and actual Boston-area employer names. To try to ensure that employers making interview decisions placed more emphasis on a candidate's schooling than years of experience, applicant resumes were designed to reflect slightly lower than average levels of relevant job experience. Work histories and skill sets were randomly and alternately associated with for-profit and community college educations and candidate names on resumes for each job application. A similar process was utilized to develop work histories and skill sets for medical assistant resumes.

Two separate resume formats were created using formatting and font guidelines from a resume creation guidebook (Bright \& Earl, 2009). These formats were randomly and alternately assigned to each job applicant. Each resume was submitted with one of two randomly determined and alternated basic cover letter messages.

The following information was collected about each job posting: employer name, contact information, and information about the position advertised (education, experience, and skill requirements). Open positions were pursued only if applications could be submitted via email or through an online application system. Accounting support and medical assistant job listings were reviewed, and applications submitted, once weekly. The voicemail account associated with each candidate's phone number was checked regularly. For every position advertised, the outcome of each candidate's application (call for interview received or call for interview not received) was recorded.

\section{Results and Discussion}

Results revealed very little difference in outcomes for job seekers with for-profit and community college credentials. However due to a low overall response rate and some issues with the experimental design, more reliable results could likely be obtained by repeating this study in a stronger economy and improving upon the method as described below.

Applications were sent to 142 open positions over the six month experimental period. One or both applicants were contacted for interviews by 21 of the employers seeking to fill positions. A breakdown of applications sent by job type and applicant's educational credential listed (community 
college or for-profit) is displayed in Table 2, along with a calculation of the net discrimination experienced by candidates with for-profit credentials. Overall, there was very little evidence to support the hypothesis that statistical discrimination may lead former for-profit students to experience disadvantages relative to their community college counterparts in the labor market.

Table 2

Job Applications Mailed and Responses Received, by Occupation and School Type

\begin{tabular}{llllllll}
\hline & $\mathrm{N}$ & $\begin{array}{l}\text { Neither } \\
\text { Occupation }\end{array}$ & $\begin{array}{l}\text { Both } \\
\text { mailed }\end{array}$ & $\begin{array}{l}\mathrm{CC} \\
\text { invited }\end{array}$ & $\begin{array}{l}\mathrm{FP} \\
\text { invited }\end{array}$ & $\begin{array}{c}\text { Net } \\
\text { discrimination a } \\
\%\end{array}$ \\
\hline $\begin{array}{l}\text { Medical } \\
\text { assistant }\end{array}$ & 88 & 78 & 4 & 3 & 3 & 0 & $0.00 \%$ \\
$\begin{array}{l}\text { Accounting, } \\
\text { bookkeeping, } \\
\text { or audit clerk }\end{array}$ & 54 & 43 & 6 & 3 & 2 & 1 & $1.85 \%$ \\
\hline Total & 142 & 121 & 10 & 6 & 5 & 1 & $0.70 \%$ \\
\hline
\end{tabular}

Note. $\mathrm{N}$ mailed $=$ number of applications mailed; Neither invited $=$ neither candidate was invited for an interview; Both invited = both candidates were invited for an interview; CC invited $=$ only the community college candidate was invited for an interview; FP invited = only the for-profit candidate was invited for an interview.

${ }^{a}$ Net discrimination percentage was calculated by subtracting the number of instances in which a for-profit candidate was the only individual invited for an interview from the number of instances in which a community college candidate was the only individual invited for an interview, and dividing by the total number of applications mailed.

Among applicants for positions in accounting, job candidates with community college credentials received slightly more calls for interviews than those with for-profit credentials, but this difference was not statistically significant. Medical assistant applications generated the same number of calls for candidates with credentials from each school type. Differences in total calls for interviews received by candidates of varying race, credential completion status, and zip code were also explored, though these were not based on matched pairs (as school types were). In both fields, "African American" candidates received fewer calls for interviews than "white" candidates. Candidates with completed credentials received a larger number of calls for interviews in the medical assisting field, but not in the accounting field. Callbacks varied by zip code (particularly among job applicants applying for medical assistant positions), but this variation was not statistically significant. Table 3 displays the number of calls received for interviews for each variable, and the $\mathrm{p}$ value associated with the significance test of differences in job callback between varied candidates. 
TESTING THE LABOR MARKET VALUE OF A FOR-PROFIT EDUCATION

Table 3

Calls for Job Interviews by Category

\begin{tabular}{lcccccc}
\hline & \multicolumn{5}{c}{ Medical assistant positions } & \multicolumn{4}{c}{ Accounting clerk positions } \\
\cline { 2 - 7 } Variable & N mailed & Calls & $p^{\text {a }}$ & N mailed & Calls & $p^{\text {a }}$ \\
\hline School type & & & & & & \\
$\quad$ Community college & 88 & 7 & 1.000 & 54 & 9 & .792 \\
$\quad$ For-profit school & 88 & 7 & & 54 & 8 & \\
Name type & & & & & & \\
$\quad$ African American & 88 & 6 & .577 & 54 & 8 & .792 \\
$\quad$ White & 88 & 8 & & 54 & 9 & \\
Credential completion & & & & & & \\
status & & & & 60 & 8 & .442 \\
$\quad$ Completed & 96 & 9 & .446 & 48 & 9 & \\
$\quad$ Partially complete & 80 & 5 & & & & \\
Zip code & & & & 28 & 4 & \\
$\quad$ Zip code 1 & 44 & 7 & & 28 & 4 & .909 \\
Zip code 2 & 44 & 4 & .118 & 28 & 4 & \\
Zip code 3 & 44 & 1 & & 24 & 5 & \\
$\quad$ Zip code 4 & 44 & 2 & &
\end{tabular}

Note. $\mathrm{N}$ mailed = number of applications mailed; Calls = calls for interviews received.

${ }^{a}$ Chi squares tests were used for the school type, race, and credential completion status data. Due to small expected values, Fisher's exact test was used for the zip code data.

The small percentage of job applications resulting in calls for interviews likely contributed to the insignificance of findings in this study. The low response rate on the part of employers may have been due to the poor state of the economy at the time that the field experiment pre-test was held. During the six month data collection period, the unemployment rate in Massachusetts averaged $7.8 \%$ (Bureau of Labor Statistics, 2013) and the nation was moving through a slow recovery in the wake of the financial crisis of 2007-08. Reflective of the level of competition in the workforce at the time of the experiment, one employer emailed a fictitious job candidate to let her know that he had received 140 applications for the open position (and the candidate was not offered an interview). In most instances, neither of the applicants in a matched pair received a call for an interviewer, indicating an employer's lack of interest in either candidate. This low level of response by employers highlights the current difficulty faced by individuals with two years of college or fewer in obtaining job interviews. Recreating this experiment in a stronger economy would likely yield a greater number of calls for interviews.

Based on the findings, there does not appear to be a relationship between school type and calls for interviews. This suggests that former forprofit students may not be at a disadvantage relative to their community college counterparts in the initial stage of a job search for positions in the selected occupational fields. However, the fact that job seekers from both school types received a similar number of calls for interviews may be 
because experience is viewed as more important than education in the types of jobs that were tested. In examining the twenty-one jobs for which fictitious candidates received calls, it was found that $86 \%$ ( 18 jobs) indicated that prior experience in the field was a necessary prerequisite, while only 9.5\% (2 jobs) listed that an associate's degree was required for consideration.

The resumes created for the fictitious job candidates in the experiment were given slightly below-average levels of experience relative to other jobs seekers, but the field of candidates from which averages were calculated did have a relatively high experience level - perhaps due to the influx of qualified employees into the labor market that accompanied rising unemployment rates during and after the economic downturn. In examining the 142 jobs posted over the course of the pre-test, those that required candidates to have a certain minimal amount of experience listed an average of 1.6 years for medical assistant jobs and 1.9 years for accounting support positions. The fictitious job candidates for medical assistant positions had just over one year of directly applicable experience, and accounting support position candidates had about three years of experience with bookkeeping tasks. Even though their resumes were created to ensure that they had less experience than typical job-seekers in the market, the fictitious job seekers were generally well qualified (in terms of experience) for the jobs posted.

Repeating this study with fictitious candidates who have just graduated from school and have no experience or extremely minimal experience (perhaps a summer job or internship) may prove a better way to test the value of a degree from a for-profit school relative to a community college in the labor market. Further, future experiments of this type may benefit from the choice of a field in which a certain level of education (e.g. an associate's degree) is widely understood to be a necessary prerequisite for entry-level positions. Looking back to the BLS list of all occupations for which women comprise at least $85 \%$ of employees and a majority of workers have an associate's degree or less, dental hygienists and preschool teachers stand out as possible fields. The BLS lists an associate's degree as the typical level of education necessary to enter each of these fields (with state licensure required of dental hygienists as well), while a high school diploma or equivalent is listed as the necessary prerequisite for entry-level medical assistant and accounting clerk positions. Thus applying for dental hygienist or preschool teacher positions with solely an associate's degree and without any relevant experience may be prove a more reliable way to gauge employer perceptions of the value of credentials from each type of school.

When repeating this study, it will also be important to expand the time period during which data collection is conducted and/or the geographic area used in order to increase the number of applications sent and responses received. Prior research using field experiments has demonstrated that many resumes must be mailed, over a large geographic 
area (potentially comprising multiple cities), in order to generate few responses. For example, Bertrand and Mullainathan's (2004) field experiment on racial discrimination in hiring involved sending applications to over 1,300 job postings in two major cities over a seven month period, and yielded a relatively low 9.65\% employer callback rate overall. Lahey (2008) sent applications to 3,996 firms in two large cities while conducting a field experiment on age discrimination in hiring over a twelve-month period spanning 2002 and 2003. In one city, just 5 percent of candidates were called for an interview, while the other city yielded an even smaller 4 percent rate of calls for interviews.

Future research focused on understanding the various ways in which postsecondary institutions may impact students' ability to perform successful job searches (make connections, create resumes reflecting marketable skills and field work experiences gained through school, and present themselves at interviews) may also shed light on the ability of different school types to impact students' capacity to obtain employment. Additionally, surveys or interviews with employers asking about their perceptions of the value of credentials from different types of postsecondary institutions may be valuable.

The results of this research indicate that, given equivalent and adequate experience levels within these job types, having a degree from a for-profit school does not appear to harm students' ability to receive calls for interviews. However, repeating this study and incorporating the suggestions discussed above would allow for a better understanding of whether or not this would be the case for individuals with little or no experience. Expanding this kind of study to other types of jobs, credential levels, and even geographic regions (as employer perceptions may change based on the reputation of various community colleges and/or for-profit schools in different cities and states) would likely generate more substantive results.

Author Notes: Correspondence concerning this article should be addressed to Carolyn Arcand, email: carolyn.arcand@unh.edu.

\section{References}

Anderson, D., Binder, M., \& Krause, K. (2003). The motherhood wage penalty revisited: experience, heterogeneity, work effort, and work-schedule flexibility. Industrial and Labor Relations Review, 56, 273-294.

Arcand, C. (2013). Understanding the risks and benefits of proprietary school attendance for low-income single mother students. Paper presented at the Annual Meeting of the New England Political Science Association, Portland, ME.

Bertrand, M. \& Mullainathan, S. (2004). Are Emily and Greg more employable than Lakisha and Jamal? A field experiment on labor market discrimination. The American Economic Review, 94, 991-1013. 


\section{ARCAND}

Bielby, W. \& Baron, J. (1986). Men and women at work: sex segregation and statistical discrimination. American Journal of Sociology, 91, 759-799.

Blau, F., Ferber, M., \& Winkler, A. (2006). The economics of women, men, and work. (5th edition). Upper Saddle River, NJ: Pearson Prentice Hall.

Bright, J. \& Earl, J. (2009). Amazing resumes. What employers want to see-and how to say it. (2nd edition). Indianapolis, IN: JIST Works.

Bureau of Labor Statistics. (2012a). Household data annual averages. Table 11: employed persons by detailed occupation, sex, race, and Hispanic or Latino ethnicity. Retrieved from http://www.bls.gov/cps/cpsaat11.htm

Bureau of Labor Statistics. (2012b). Employment projections. Table 1.11: educational attainment for workers 25 years and older by detailed occupation, 2009. Retrieved from http://www.bls.gov/emp/ep_table_111.htm

Bureau of Labor Statistics. (2013). Labor Force Statistics from the Current Population Survey. Retrieved from http://data.bls.gov/timeseries/LNS14000000

Center for Women Policy Studies. (2004). A profile of low income women students in postsecondary educational institutions. Washington, DC: Center for Women Policy Studies.

Cohen, A. \& Kisker, C. (2009). Shaping of American higher education: emergence and growth of the contemporary system. Hoboken, NJ: Jossey-Bass.

Craigslist >about>factsheet. (2012). Retrieved from http://www.craigslist.org/about/factsheet

Figart, D., Mutari, E., \& Power, M. (2002). Living wages, equal wages: gender and labor market policies in the United States. Florence, KY: Routledge.

Gross, J., Cekic, O., Hossler, D., \& Hillman, N. (2009). What matters in student loan default: a review of the research literature. Journal of Student Financial Aid, 39, 19-29.

Harkin, T. (2010, December 14). For profit investigation. Senate floor video. Retrieved from http://harkin.senate.gov/help/video_floor.cfm\#1

Institute for Women's Policy Research. (2011). The gender wage gap: 2010. IWPR \# C350. Washington, DC: Institute for Women's Policy Research.

Jepsen, C. \& Montgomery, M. (2009). Miles to go before I learn: the effect of travel distance on the mature person's choice of a community college. Journal of Urban Economics, 65, 6473.

Kutz, G. (2010, August 4). Undercover testing finds colleges encouraged fraud and engaged in deceptive and questionable marketing practices. Testimony before the Committee on Health, Education, Labor, and Pensions, U.S. Senate.

Lahey, J. (2008). Age, women, and hiring. An experimental study. Journal of Human Resources, 43, 30-56.

Levine, A. \& Nidiffer, J. (2006). Beating the odds. How the poor get to college. San Francisco, CA: Jossey-Bass Inc. Publishers.

Loonin, D. (2012). The student loan default trap. Why borrowers default and what can be done. Boston, MA: National Consumer Law Center.

Lynch, M., Engle, J., \& Cruz, J. (2010). Subprime opportunity: the unfulfilled promise of forprofit colleges and universities. Washington, DC: The Education Trust.

Miller, K. (2012). Fact sheet. Single student parents face financial difficulties, debt, without adequate aid. IWPR \#C394. Washington, DC: Institute for Women's Policy Research.

Pager, D., Bonikowski, B., \& Western, B. (2009). Discrimination in a low-wage labor market: a field experiment. American Sociological Review, 74, 777-799.

Phelps, E. (1972). The statistical theory of racism and sexism. The American Economic Review, 62, 659-661.

Shontell, A. (2012, February 21). How indeed.com, the world's largest job search site, exploded to 60 million uniques. Business Insider. Retrieved from http://www.businessinsider.com/

Swail, W. (2009). Graduating at-risk students: a cross-sector analysis. Washington, DC: Imagine America Foundation. 
U.S. Department of Education. (2012). FY 2009 official national 3-year cohort default rates. Retrieved from http://www2.ed.gov/offices/OSFAP/defaultmanagement/cdrschooltype3yr.pdf

Widner, D. \& Chicoine, S. (2011). It's all in a name: employment discrimination against Arab Americans, Sociological Forum, 26, 806-823.

Yeoman, B. (2011). The high price of for-profit colleges. Academe 97(3). Retrieved from www.aaup.org/AAUP/pubsres/academe/2011/MJ/Feat/eom.htm 